Int. J. Electrochem. Sci., 14 (2019) $3932-3948$

International Journal of

ELECTROCHEMICAL

SCIENCE

www.electrochemsci.org

\title{
Corrosion Inhibition and Adsorption Behavior of Nerium Oleander Extract on Carbon Steel in Hydrochloric Acid Solution
}

\author{
A.S. Fouda ${ }^{* 1}$, M. Abdel Azeem ${ }^{2}$, S.A.Mohamed ${ }^{2}$, A.El-Hossiany ${ }^{3}$ and E. El-Desouky ${ }^{1}$ \\ ${ }^{1}$ Department of Chemistry, Faculty of Science, El-Mansoura University, El-Mansoura-35516, Egypt, \\ ${ }^{2}$ Department of Chemistry, Faculty of Science, Menoufia University, Shibin El-Kom-32511, Egypt \\ ${ }^{3}$ Chemist, Delta Fertilizers Company in Talkha, Egypt. \\ *E-mail: asfouda@hotmail.com
}

doi: $10.20964 / 2019.04 .44$

Received: 31 November 2018 / Accepted: 21 January 2019 / Published: 10 March 2019

Nerium Oleander (N. Oleander) was investigated as a corrosion inhibitor for carbon steel (CS) in $1 \mathrm{M}$ $\mathrm{HCl}$ solution using electrochemical techniques (potentiodynamic polarization (PP), electrochemical impedance spectroscopy (EIS) and electrochemical frequency modulation (EFM)) and nonelectrochemical method (weight loss (WL)). The data showed that the inhibition protection (\%IP) raised and corrosion rate (CR) lowered with raising both NOE concentration and temperature to reach $91 \%$ at300 ppm. The adsorption of the NOE on CS surface was found to obey the Langmuir's adsorption isotherm. The PP curves showed that this extract behaved as a mixed type inhibitor. Fourier transform infrared (FT-IR) was utilized to detect the functional groups adsorbed on CS surface. Surface morphology was examined using scanning electron microscope (SEM) and atomic force microscopy (AFM) techniques.

Keywords: Inhibition protection, Carbon steel, N. Oleander extract, HCl, SEM, AFM

\section{$\underline{\text { FULL TEXT }}$}

(C) 2019 The Authors. Published by ESG (www.electrochemsci.org). This article is an open access article distributed under the terms and conditions of the Creative Commons Attribution license (http://creativecommons.org/licenses/by/4.0/). 